\title{
Evaluation of temperature-induced effects on safety-relevant properties of clay host rocks with regard to HLW/SF disposal
}

\author{
M. JobManN ${ }^{1, *}$ AND A. Meleshyn ${ }^{2}$ \\ 1 DBE TECHNOLOGY GmbH, Eschenstraße 55, D-31224 Peine, Germany \\ 2 Gesellschaft für Anlagen- und Reaktorsicherheit (GRS) gGmbH, Theodor-Heuss-Straße 4, D-38122 Braunschweig, \\ Germany
}

[Received 23 October 2014; Accepted 17 May 2015; Associate Editor: Nicholas Bryan]

\section{ABSTRACT}

DBE TECHNOLOGY, BGR and GRS are developing a methodology to demonstrate the safety of a repository for high-level waste and spent fuel (HLW/SF) in clays according to the requirements of the German regulating body. In particular, these requirements prescribe that the barrier effect of host rocks must not be compromised by a thermal impact resulting from HLW/SF emplacement. To substantiate and quantify this requirement, we carried out a literature survey of research on thermally-induced changes on clay properties. Effects thus compiled can be divided into thermo-hydro-mechanical and chemical-biologicalmineralogical effects and were analysed with regard to their relevance to the integrity of clay host rocks. This analysis identified one effect of major influence within each group: thermal expansion and compaction as well as results of microbial activities. Importantly, it further revealed that a moderate temperature increase above $100^{\circ} \mathrm{C}$ cannot be expected to compromise the integrity of the geological barrier according to the current knowledge state. Evidence is presented in this paper that temperature increases up to $150^{\circ} \mathrm{C}$ can actually contribute to an improved performance of a radioactive waste repository by increasing the consolidation of the clay and sterilizing the repository's near-field to depress the deteriorative microbial effects. A quantitative temperature criterion for thermal impact of HLW/SF on clay host rocks is accordingly proposed.

KEYWORDs: geological barrier, temperature criterion, barrier integrity, host rock, safety.

\section{Introduction}

An integrated methodology to demonstrate the safety of a HLW/SF-repository in clays in Germany is being developed by DBE TECHNOLOGY, BGR (Bundesanstalt für Geowissenschaften und Rohstoffe) and GRS. The strength of this new integrated methodology lies in the link between legal and geological boundary conditions, disposal

* E-mail: jobmann@dbe.de

DOI: $10.1180 /$ minmag.2015.079.6.14 and closure concept, demonstration of integrity of the geological and geotechnical barriers, and longterm analysis of probable and less probable repository evolutions.

One key element is the demonstration of the integrity of the geological barrier. The regulating body requires a demonstration of the integrity of the containment-providing rock zone within host rocks for a period of 1 million years by meeting different integrity criteria (BMU, 2010). In particular, one of these criteria prescribes that the barrier effect of host rocks must not be compromised by temperature effects resulting from HLW/SF emplacement.
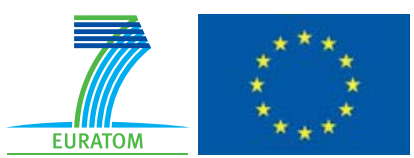

The publication of this research has been funded by the European Union's European Atomic Energy Community's (Euratom) Seventh Framework programme FP7 (2007-2013) under grant agreements $n^{\circ} 249396$, SecIGD, and n`323260, SecIGD2. 
In order to be able to carry out such a demonstration which necessarily involves a model effort, this qualitative requirement needs a quantification to identify the corresponding limiting temperature (temperature criterion).

\section{Effects of temperature on host-rock properties}

A key question in this relation concerns a definition of the compromising thermal impact on clays. To answer this question, a literature survey was carried out focusing on research of thermally induced changes of clay properties. The effects thus compiled have been categorized into thermohydro-mechanical and chemical-biologicalmineralogical effects and were analysed with regard to their relevance to the geological barrier integrity as described below. A more detailed description prepared by the authors in the course of the study will be published as a technical report following this publication (Jobmann et al., 2015).

\section{Thermo-hydro-mechanical effects}

Laboratory tests with saturated Boom Clay (Sultan et al., 2002; Baldi et al., 1991) showed in accordance with earlier observations for other saturated clays (Tang et al., 2008) that heating of compacted or natural clay causes the clay to contract if the overconsolidation ratio (OCR, a ratio of vertical effective pre-consolidation stress to the current effective stress) is low $(\leq 1)$. At highOCR values, an initial period of thermal expansion turns into contraction upon exceeding a specific temperature as shown in Fig. 1.

While thermal expansion of clays takes place due to a thermal expansion of the clay matrix and of pore water, thermal contraction of clays is due to mechanical reduction of the intergranular friction. As a result of this compaction, the strength of the clay increases irreversibly (Tang et al., 2008). The mechanical reduction of the intergranular friction can indeed involve the release of water adsorbed between layers and on the surface of clay minerals. The initial expansion of the material at increasing temperatures due to the expansion of the mineral matrix and of the pore water is followed by a phase where expansion and contraction counterbalance each other until the release of water and thus the contraction (consolidation) prevails (Jobmann and Polster, 2007). But even if the claystone is nearly saturated or almost undrained, contraction takes place if the temperature at the expansioncontraction-threshold (ECT) is exceeded (Zhang et al., 2010).

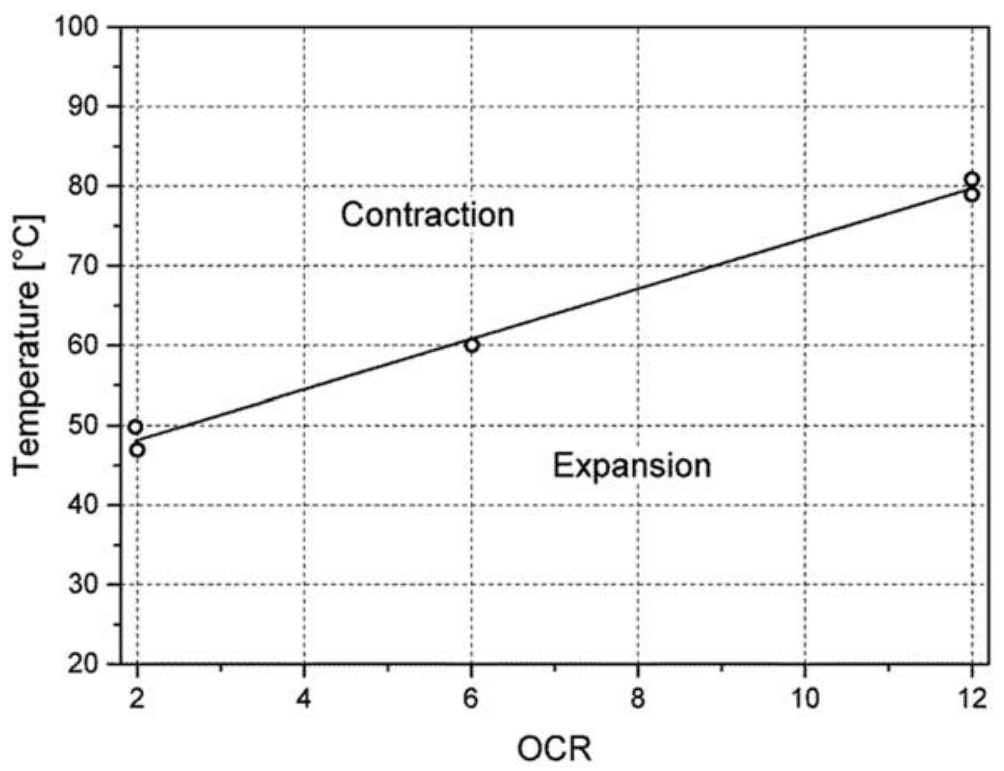

FIG. 1. Temperature at the expansion-contraction-threshold as a function of overconsolidation ratio (OCR) for Boom Clay (modified after Sultan et al., 2002; Baldi et al., 1991). 
The ECT also depends on the stress state and suction. Following an increase in intergranular friction with high-suction tension the ECT shifts to higher temperatures. This is consistent with the results from triaxial tests using core samples of Callovo-Oxfordian clay (Zhang et al., 2010) in which thermal expansion took place at $90^{\circ} \mathrm{C}$ in drained samples (higher suction tension) and thermal contraction took place in undrained samples (lower suction tension). The increasing effective stress, on the contrary, reduces the ECT. Experiments of Faulkner and Rutter (2003) with clay samples from fault gouges for example, document an ECT decrease from $80^{\circ} \mathrm{C}$ at $25 \mathrm{MPa}$ to $40^{\circ} \mathrm{C}$ at $50 \mathrm{MPa}$. Importantly, the thermal contraction in clay persists even after subsequent cooling, while thermal expansion is reversible (Tang et al., 2008).

During the large-scale in situ test in Boom clay, a shift from expansion at $\mathrm{OCR}=6$ to compaction at $\mathrm{OCR}=2$ to an even stronger compaction at $\mathrm{OCR}=1$ were observed between $20-95^{\circ} \mathrm{C}$ (François et al., 2009). As a result of this compaction, the strength of the clay and the pre-consolidation pressure in the clay increased irreversibly. From heater test results in Opalinus clay, it was concluded that neither the heating nor the subsequent cooling caused thermally induced cracks in the clay (Kull et al., 2007; Zhang et al., 2007).

Mechanical properties of Opalinus clay obtained at temperatures between 60 and $80^{\circ} \mathrm{C}$ revealed a slightly reduced breaking strength, residual strength and Young's modulus when compared to results obtained at 20 to $35^{\circ} \mathrm{C}$ (Gräsle and Plischke, 2010). However, these laboratory tests were carried out in a temperature range that is below the ECT, i.e. in the expansion phase. A thermal contraction, in contrast, generally increases the strength and rigidity of clays. Zhang et al. (2010) analysed rock samples of the Callovo-Oxfordian clay at temperatures between 90 and $150^{\circ} \mathrm{C}$, which is above the ECT, and found that the strength of the clay had increased significantly under thermal load.

With regard to hydraulic properties, laboratory experiments on clay samples taken from claybearing fault gouges showed that water permeability increases with increasing temperature from $20^{\circ} \mathrm{C}$ to $80^{\circ} \mathrm{C}$. A further increase of the temperature above $80^{\circ} \mathrm{C}$ up to $150^{\circ} \mathrm{C}$ resulted in a continuous decrease of the water permeability (Faulkner and Rutter, 2003). The behaviour in the lower temperature range $<80^{\circ} \mathrm{C}$ was assumed to be caused by the increasing de-stabilization and desorption of water adsorbed at the mineral surfaces which reduced the water permeability. At higher temperatures, the compaction process is dominant, leading to a reduction in porosity and permeability. At effective stresses below $75 \mathrm{MPa}$, no changes in water permeability were observed in the low-temperature range $<80^{\circ} \mathrm{C}$ which was assumed to be due to pore dilation. Even at such relatively low effective stresses, a continuous decrease of the water permeability was observed at temperatures higher than $80^{\circ} \mathrm{C}$. These observations are in agreement with laboratory experiments on Callovo-Oxfordian clay (Zhang et al., 2010).

Heating of saturated clay leads to an increase in pore pressure due to the thermal expansion of the pore fluid. Due to the increase in pore pressure in clay host rocks, the resistance to gas penetration is increased as well, because the gas has to overcome this increased resistance before it can penetrate the rock mass.

Additionally, an increase in pore pressure generates hydraulic pressure gradients, causing the pore fluids to migrate. The rate of the migration process and thus of pressure decrease depends on the permeability of the clay (Jobmann et al., 2007; Zhang et al., 2010). This process is temporary and reversible as long as no fractures are induced. Experience from the in situ heater experiments shows that pore pressure decreases over a period of approximately one year without inducing any fractures.

Water in the host rock next to the waste vapourizes after exceeding the boiling point. Taking into account the hydrostatic pressure at the emplacement level, it becomes clear, however, that the boiling point under emplacement conditions of an overburden pressure of $\sim 7 \mathrm{MPa}$ will be at $\sim 280^{\circ}$ C. Even a small fluid pressure increase of $0.5 \mathrm{MPa}$ after sealing, for instance, increases the boiling point to $\sim 150^{\circ} \mathrm{C}$.

As for the thermal properties of clay, the contraction in Opalinus clay results, for example, in a slight increase in thermal conductivity at temperatures above $110^{\circ} \mathrm{C}$, which is due to a closer contact in the mineral matrix and the reduced pore space (Jobmann and Polster, 2007).

\section{Chemical, biological and mineralogical effects}

A temperature-dependent conversion of smectite to illite can considerably deteriorate the retention properties of clay. It is important to note that the smectite-to-illite reaction requires potassium to proceed. Huang et al. (1993) showed that for a K content of $200 \mathrm{ppm}$, which is characteristic of clays, an illitization of $80 \%$ of smectite cannot be 
accomplished before 100,000 years at $\sim 150^{\circ} \mathrm{C}$ (Fig. 2). The latter study concluded that the observations by Pytte and Reynolds (1989) of shorter smectite-to-illite reaction times for contact metamorphic fluids $\left(\sim 3500\right.$ years at $\sim 150^{\circ} \mathrm{C}$ for an illitization of $50 \%$ of smectite) must be due to an order of magnitude higher K content of $>2000$ ppm, which is characteristic of hydrothermal fluids. Considering that the thermal impact of the emplaced HLW/SF becomes negligible after about 10,000 years (Jobmann et al., 2015), being constrained to several metres around individual boreholes or tunnels with $\mathrm{HLW} / \mathrm{SF}$ even at the temperature maximum, no significant illitization within clay host rocks can be expected to occur.

Dissolution of $\mathrm{SiO}_{2}$ in clay represents a further possible effect of heating, which at subsequent cooling is followed by its re-precipitation, leading to a cementation of pores and influencing plasticity, hydraulic conductivity and swelling capacity of clay (Wersin et al., 2007). The latter study concluded however that this effect causes no or only minor changes of these clay properties at temperatures of $<130^{\circ} \mathrm{C}$.

Thermo-chemical sulfate reduction is proved to occur during geological times at temperatures $>80^{\circ} \mathrm{C}$. At $90^{\circ} \mathrm{C}$, the extrapolated half-life of the sulfate reduction is $\sim 210,000$ years (Truche et al., 2009).
According to Cross et al. (2004) half of sulfate in clay pore water can be reduced to corrosive hydrogen sulfide within about 1650 years at $150^{\circ} \mathrm{C}$ or within $\sim 20,000$ years at $125^{\circ} \mathrm{C}$. Assuming that the temperature of the host rocks will not exceed $150^{\circ} \mathrm{C}$ at any place, the time period of temperatures above $80^{\circ} \mathrm{C}$ in the host rocks will be a few hundred years only. Thus, no significant sulfate reduction is to be expected and will be limited to a relatively short time period and to the closest vicinity of emplacement drifts or boreholes.

Quantitative analysis of retention behaviour of clay at increased temperatures can be derived from experimental values of sorption capacities or distribution coefficients $(K d)$ of radionuclides for individual minerals constituting the clay. Very limited available data on distribution coefficients for clay minerals and dependence on temperature reveal that $K d$ increases for $\mathrm{Ni}, \mathrm{Eu}$, and other lanthanides and slightly decreases for Cs for temperature increasing from 20 to $150^{\circ} \mathrm{C}$ (Jobmann et al., 2015). Since Cs is not a dose-relevant nuclide for a deep geological disposal in clays and the temperature increase is limited to a few thousand years this effect can be judged to be irrelevant.

Transformation of organics to raw oil and natural gas was recently studied using a numerical model calibrated by measured vitrinite reflectance, which

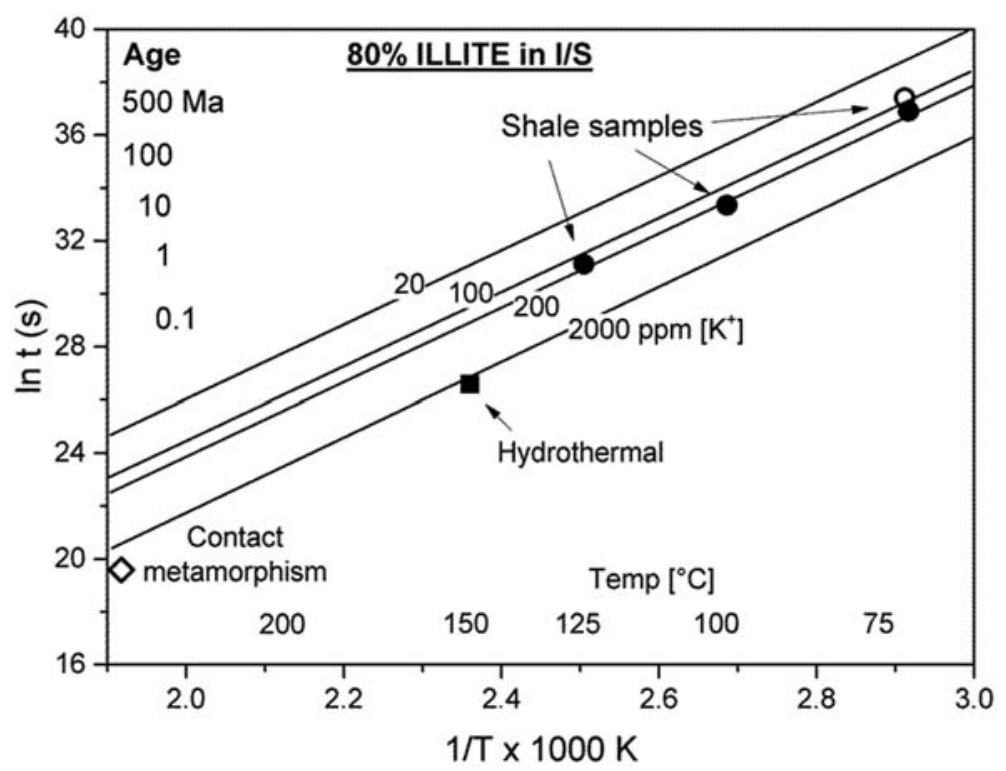

FIG. 2. Evolution of the smectite content in mixed-layer illite/smectite with time depending on the clay temperature and potassium content (From Huang et al. (1993, figure 7). Reproduced with kind permission of The Clay Minerals Society, publisher of Clays and Clay Minerals). 
is an index for the transformation, in the vicinity of a basalt intrusion. Recent calculations yield that the heat input will be limited to 10,000 years and temperatures of $100-150^{\circ} \mathrm{C}$ and is extremely small when compared to that of a basalt intrusion with a temperature of $\sim 1200^{\circ} \mathrm{C}$ and a heating period of 100 million years. The changes in the values of vitrinite reflectance due to the HLW/SF were found to be extremely small (Jobmann et al., 2013).

Results of extensive experimental studies on microbial activities in clays allow identification of microbial processes which can influence the longterm performance of a deep geological repository for HLW/SF in clay (Meleshyn, 2014). Most important microbial activities are those influencing clay alteration and gas production, which can be expected to be most pronounced in the excavationdamaged zone of host rocks due to increased pore space. Activity of sulfate-reducing bacteria (through production of sulfide) as well as $\mathrm{Fe}(\mathrm{III})$ reducing bacteria (direct reduction of $\mathrm{Fe}(\mathrm{III})$ in the clay structure) can negatively influence retention properties of clay as a result of the clay mineral alteration. Along with the other microbial and abiotic gas production processes methane production can lead to an over-pressure and formation of cracks. According to the current state of knowledge (Meleshyn, 2014), methanogen microbes remain active up to $122^{\circ} \mathrm{C}$, whereas sulfate-reducing bacteria can survive at such temperatures only in an inactive state. They were proved however to have an optimum growth at $80-95^{\circ} \mathrm{C}$. Therefore, heating of the clay in excess of $122^{\circ} \mathrm{C}$ can lead to a considerable decline of microbial population and of microbial activity in the near field of a repository.

\section{Evaluation of the temperature effects with regard to long-term safety}

\section{Evaluation of the thermo-hydro-mechanical effects}

Heating of the clay to temperatures below the ECT $\left(50\right.$ to $\left.80^{\circ} \mathrm{C}\right)$ generally has a slightly negative effect on its mechanical properties. Heating to temperatures above the ECT up to $\sim 150^{\circ} \mathrm{C}$, on the contrary, has a positive effect on the thermal conductivity, mechanical strength and stiffness of clay. If the temperature rises above the ECT in the near-field around the waste canisters, irreversible consolidation in that part of the host rocks counterbalances the thermal expansion.

Water permeability increases with temperature up to $\sim 80^{\circ} \mathrm{C}$ and decreases afterwards up to $150^{\circ} \mathrm{C}$.
Heating increases the pressure required for gas penetration into the clay. Water evaporation will only take place temporarily during the re-saturation. Subsequently, the boiling point of pore water will increase to $\sim 280^{\circ} \mathrm{C}$ due to the pressure increase.

Based on current knowledge, the analysis of the thermo-hydro-mechanical effects reveals no deterioration but does reveal a positive impact of a temperature increase beyond the ECT $\left(50-80^{\circ} \mathrm{C}\right)$ up to $150^{\circ} \mathrm{C}$ on the barrier properties of host rocks.

\section{Evaluation of the chemical-biological- mineralogical effects}

The period during which the thermal input of a HLW/ SF repository heats the host rocks to temperatures relevant for abiotic chemical and mineralogical processes only within a limited period of time and within a distance limited to several metres around the emplacement boreholes or tunnels. During this time no appreciable abiotic illitization (and thus no change in swelling properties) thermochemical sulfate reduction or kerogen transformation to raw oil and natural gas is to be expected. However, substantial illitization, sulfate reduction and natural gas production can occur at much lower temperatures if driven microbially. A temperature increase above $122^{\circ} \mathrm{C}$ will lead to a considerable decline of the population and activity of sulfate- and Fe(III)-reducing as well as methane-producing microbial species and thus will potentially improve the repository performance. The positively regarded smectitization of illite possibly occurs within this time, but still to a non-appreciable extent. The influence of the cementation through silica and illite neo-formation on the barrier performance of clay as well as possible changes of sorption properties at temperatures $\leq 150^{\circ} \mathrm{C}$ can be judged as negligible too.

Sulfate- and $\mathrm{Fe}(\mathrm{III})$-reducing bacteria can build endospores enhancing their resistance to unfavourable environmental conditions. The lethal temperatures for bacteria in an endospore state are $30-40^{\circ} \mathrm{C}$ higher than those for bacteria in an active state (Nicholson et al., 2000). The upper temperature limit for the activity of sulfate- and $\mathrm{Fe}(\mathrm{III})$-reducing bacteria is at about $95^{\circ} \mathrm{C}$ and $122^{\circ} \mathrm{C}$ respectively. Therefore, a relatively short thermal treatment at $\sim 150^{\circ} \mathrm{C}$ will be necessary in order to eliminate possible endospores in a repository material. With increasing duration of the thermal treatment, the elimination temperature can be expected to decrease according to the observation of only spurious or even no microbial biomass in 
sedimentary rocks exposed to palaeo-temperatures of $140^{\circ} \mathrm{C}$ or $145^{\circ} \mathrm{C}$, respectively, during their diagenesis (Colwell et al., 1997). Summarizing, the surviving microbial population in clay will decrease with increasing temperature and duration of the thermal treatment in excess of $122^{\circ} \mathrm{C}$.

\section{Final evaluation and definition of the temperature criterion}

The above-discussed possible effects of increased temperatures on the barrier properties of the host rocks are summarized in Table 1. It should be noted here that most studies were carried out at temperatures below $\sim 150^{\circ} \mathrm{C}$, so that for higher temperatures no evaluation can be made based on the current state of knowledge. As a result of the

TABLE 1. Evaluation of the thermally induced effects in clay with respect to the impact on its barrier properties (ECT $=$ Expansion-Contraction-Threshold) based on available studies for temperatures from $20^{\circ} \mathrm{C}$ to $150^{\circ} \mathrm{C}$.

\begin{tabular}{|c|c|c|}
\hline No. & Thermally-induced effect & Impact evaluation \\
\hline \multicolumn{3}{|c|}{ Thermo-hydro-mechanical effects } \\
\hline 1 & $\begin{array}{l}\text { Expansion/contraction of } \\
\text { claystone }\end{array}$ & $\begin{array}{l}T<\text { ECT: negative } \\
T>\text { ECT: positive }\end{array}$ \\
\hline 2 & Mechanical properties & $\begin{array}{l}T<\text { ECT: negative } \\
T>\text { ECT: positive }\end{array}$ \\
\hline 3 & Hydraulic properties & $\begin{array}{l}T<\text { ECT: negative } \\
T>\text { ECT: positive }\end{array}$ \\
\hline 4 & Thermal properties & $\begin{array}{l}T<\text { ECT: negative } \\
T>\text { ECT: positive }\end{array}$ \\
\hline 5 & Swelling pressure & Negligible \\
\hline 6 & $\begin{array}{l}\text { Dehydration of swelling clay } \\
\text { minerals }\end{array}$ & Negligible \\
\hline 7 & $\begin{array}{l}\text { Generation of hydraulic } \\
\text { gradients }\end{array}$ & Negligible \\
\hline 8 & Vapourization & Negligible \\
\hline 9 & Gas entry pressure & Negligible \\
\hline \multicolumn{3}{|c|}{ Chemical, biological, and mineralogical effects } \\
\hline 10 & Illitization of smectites & Negligible \\
\hline 11 & Smectitization of illites & $\begin{array}{l}\text { Positive, while } \\
\text { negligible }\end{array}$ \\
\hline 12 & $\begin{array}{l}\text { Cementation by generation } \\
\text { of silica and new minerals }\end{array}$ & Negligible \\
\hline 13 & $\begin{array}{l}\text { Thermo-chemical sulfate } \\
\text { reduction }\end{array}$ & Negligible \\
\hline 14 & Sorption properties & Negligible \\
\hline 15 & Kerogen transformation & Non existent \\
\hline 16 & Microbial activities & $\begin{array}{l}T<122^{\circ} \mathrm{C} \text { : negative } \\
T>122^{\circ} \mathrm{C} \text { : positive }\end{array}$ \\
\hline
\end{tabular}

evaluation, two processes can be identified as significant: thermal expansion and contraction from the group of the thermo-hydro-mechanical processes as well as microbial activity from the group of the chemical-biological-mineralogical processes.

The impact of increased temperatures on the expansion and contraction can be concluded to be positive as soon as the temperature in the clay host rock exceeds the ECT and as long as the pore pressure due to the thermal expansion of pore fluid, possibly in combination with the thermally induced contraction of the solids, does not lead to fissuring. Besides, along with the repository fields with $T>$ ECT in the close vicinity of the emplaced HLW/SF there are expected to be zones with increased temperatures below the ECT, where rock properties will be influenced negatively. Such zones are however unavoidable in any design of HLW/SF repositories.

Similarly, the impact of increased temperatures on microbial activity can be concluded to be positive as soon as the temperature in the clay exceeds $122^{\circ} \mathrm{C}$ by several degrees for several tens or hundreds of years. This would lead not only to a temporal prohibition of the microbial activity able to substantially deteriorate barrier properties of clay, but also to a strong decline of microbial populations in, or even to a temporal "sterilization" of the excavation-damaged zone. Such a sterilization can have a sustainable effect, as a recolonization of this part of the host rock along with its cooling-down would be prevented by its irreversible consolidation at $T>\mathrm{ECT}$.

As a result, the temperature criterion is proposed as follows:

"It has to be demonstrated that a temperature of $150^{\circ} \mathrm{C}$ will not be exceeded in host rocks".

This temperature limit allows development of a disposal concept that considers the possibility of a sterilized zone around the waste canisters. The limit is set to $150^{\circ} \mathrm{C}$ in view of the lack of relevant studies and information for higher temperatures.

\section{Conclusions}

Besides some slight negative effects of heating clay up to $\sim 80^{\circ} \mathrm{C}$, a temperature increase up to $150^{\circ} \mathrm{C}$ leads, amongst others, to increases in thermal conductivity, mechanical strength, and stiffness of the clay, as well as to limiting microbial activities as soon as the environmental temperature exceeds $122^{\circ} \mathrm{C}$ by several degrees. Thus, heating clay host 
rocks does not necessarily compromise but may actually improve the barrier performance.

\section{Acknowledgements}

The authors thank the Federal Ministry for Economics and Technology (BMWi) for funding the described research and development activities and are grateful for the helpful and very constructive comments from three reviewers.

\section{References}

Baldi, G., Hueckel, T., Peano, A. and Pellegrini, R. (1991) Developments in modelling of thermo-hydrogeomechanical behaviour of Boom clay and claybased buffer materials. Technical Report, Volume 1, European Commission, EUR13365/1EN.

BMU (2010) Safety Requirements Governing the Final Disposal of Heat-Generating Radioactive Waste. Bundesministerium für Umwelt, Naturschutz und Reaktorsicherheit.

Colwell, F.S., Delwiche, M.E., Chandler, D., Fredrickson, J.K., Yao, Q.J., McKinley, J.P. et al. (1997) Microorganisms from deep, high temperature sandstones: constraints on microbial colonization. FEMS Microbiology Reviews, 20, 425-435.

Cross, M.M., Bottrell, S.H., Manning, D.A. and Worden, R.H. (2004) Thermo-chemical sulfate reduction (TSR), experimental determination of reaction kinetics and implications of the observed reaction rates for petroleum reservoirs. Organic Geochemistry, 35, 393-404.

Faulkner, D. and Rutter, E. (2003) The effect of temperature, the nature of the pore fluid, and subyield differential stress on the permeability of phyllosilicate-rich fault gouge. Journal of Geophysical Research, 108, B5.

François, B., Laloui, L. and Laurent, C. (2009) Thermohydro-mechanical simulation of ATLAS in-situ large scale test in Boom Clay. Computers and Geotechnics, 36, 626-640.

Gräsle, W. and Plischke, I. (2010) LT Experiment. Mechanical Behaviour of Opalinus Clay. Final report from Mt. Terri phases 6-14. Technical Report, BGR.

Huang, W., Longo, J. and Pevear, D. (1993) An experimentally derived kinetic model for smectite-toillite conversion and its use as a geothermometer. Clays and Clay Minerals, 41, 162-177.

Jobmann, M. and Polster, M. (2007) The response of Opalinus clay due to heating: A combined analysis of in-situ measurements, laboratory investigations and numerical calculations. Physics and Chemistry of the Earth, 32, 929-936.

Jobmann, M., Uhlig, L., Amelung, P., Billaux, D., Polster, M. and Schmidt, H. (2007) Untersuchungen zur sicherheitstechnischen Auslegung eines generischen
Endlagers im Tonstein in Deutschland. Technical Report, DBE TECHNOLOGY GmbH.

Jobmann, M., Breustedt, M., Li, S., Polster, M. and Schirmer, S. (2013) Investigations on THM Effects in Buffer, EDZ and Argillaceous Host Rock. Final Report, DBE TECHNOLOGY GmbH.

Jobmann, M., Maßmann, J., Meleshyn, A. and Polster, M. (2015) Quantification of Criteria for Integrity Demonstation in Clay. Technical Report, DBE TECHNOLOGY, BGR, GRS (in preparation).

Kull, H., Jockwer, N., Zhang, C.L., Wileveau, Y. and Pepa, S. (2007) Measurement of thermally induced pore-water pressure increase and gas migration in the Opalinus Clay at Mont Terri. Physics and Chemistry of the Earth, 32, 937-946.

Meleshyn, A. (2014) Microbial processes relevant for the long-term performance of radioactive waste repositories in clays. Clays in Natural and Engineered Barriers for Radioactive Waste Confinement. Geological Society, London, Special Publications, 400, http://dx. doi.org/10.1144/SP400.6.

Nicholson, W. L., Munakata, N., Horneck, G., Melosh, H., Melosh, J. and Setlow, P. (2000) Resistance of Bacillus endospores to extreme terrestrial and extraterrestrial environments. Microbiology and Molecular Biology Reviews, 64, 548-572.

Pytte, A. and Reynolds, R. (1989) The thermal transformation of smectite to Illite. Pp. 133-140 in: Thermal History of Sedimentary Basins (M.C. Naer and T.H. McCulloh, editors). Chapter 8. Springer, New York.

Sultan, N., Cui, Y. and Delage, P. (2002) Temperature effects on the volume change behaviour of Boom clay. Engineering Geology, 64, 135-145.

Tang, A.-M., Barnel, N. and Cui, Y.-J. (2008) Thermomechanical behaviour of a compacted swelling clay. Géotechnique, 58, 45-54.

Truche, L., Berger, G., Destrigneville, C., Guillaume, D., Giffaut, E. and Pages, A. (2009) Experimental reduction of aqueous sulphate by hydrogen under hydrothermal conditions: implication for the nuclear waste storage. Geochimica et Cosmochimica Acta, $\mathbf{7 3}$, 4824-4835.

Wersin, P., Johnson, L. and McKinley, I. (2007) Performance of the bentonite barrier at temperatures beyond $100^{\circ} \mathrm{C}$ : A critical review. Physics and Chemistry of the Earth, 32, 780-788.

Zhang, C.-L., Rothfuchs, T., Jockwer, N., Wieczorek, K., Dittrich, J., Müller, J., et al. (2007) Thermal Effects on the Opalinus Clay. A Joint Heating Experiment of ANDRA and GRS at the Mont Terri URL (HE-D Project). GRS-224. Final report, GRS.

Zhang, C.-L., Czaikowski, O. and Rothfuchs, T. (2010) Thermo-hydro-mechanical Behaviour of the Callovo-Oxfordian Clay Rock. GRS-266. Final report, GRS. 